\title{
Trafik Gürültüsünü Etkileyen Faktörlerin SoundPlan 6.5 Programı ile İncelenmesi
}

\author{
Aybike ÖNGEL ${ }^{1}$ \\ Fatih SEZGIN $^{2}$
}

Öz

Ulaştırma kaynaklı gürültü kirliliği son yıllarda tüm dünyadaki en büyük çevresel sorunlardan biri haline gelmiştir. Gürültünün duyma kaybı, performans kaybı, rahatsızlık, uyku bozuklukları, kardiyovasküler problemler ve çocuklarda zihinsel bozukluklar gibi sağlık üzerine olumsuz etkileri vardır. Bu araştırmada, SoundPlan 6.5 gürültü haritalama programı kullanılarak D-100 Karayolu Okmeydanı mevkisi için gürültü haritaları oluşturulmuştur. Gürültüyü etkileyen faktörler olan trafik hacmi, kompozisyonu, hızı ve yol üstyapı tipinin gürültü maruziyeti,rahatsızlık, uyku bozuklukları ve kardiyovasküler hastalık riskine olan etkileri gürültü haritaları kullanılarak incelenmiş̧ir. Bu çalışmalar sonucunda, hız limiti, toplu taşıma, ağır taşıt ve yol üstyapı türü bağlamında alınabilecek tedbirler önerilmiştir.

Anahtar Kelimeler: Karayolu gürültüsü, SoundPlan, gürültü haritası, gürültü ve sağlık.

\begin{abstract}
Evaluation of Effects of Traffic Variables on the Noise Levels Using SoundPlan V6.5

In recent decades, noise pollution has been a worldwide concern. The health effects of noise pollution include noise-induced hearing loss, sleep disturbance, performance loss, annoyance, cardiovascular problems, and cognitive impairment in children. In this study, noise maps were prepared using SoundPlan 6.5 for D-100 Highway around Okmeydani. The effects of traffic volume, composition, and speed and pavement surface type on the number of people exposed to noise levels above threshold for annoyance, sleep disturbance, and cardiovascular diseases were investigated. Noise reduction strategies in terms of speed limit, public transportation, heavy vehicle traffic, and pavement type were proposed.
\end{abstract}

Keywords: Highway noise, SoundPlan, noise map, noise and health.

Not: Bu yaz1

- $\quad$ Yayın Kurulu'na 12.06.2014 günü ulaşmıştır.

- 31 Mart 2017 gününe kadar tartışmaya açıktır.

1 İstanbul Ticaret Üniversitesi, İnşaat Mühendisliği Bölümü, İstanbul - aybike@gmail.com

2 İstanbul Büyükşehir Belediyesi, Çevre Koruma Müdürlüğü, İstanbul - fatih.sezgin@ibb.gov.tr 


\section{GíRiş}

Gürültü, istenmeyen ve hoş olmayan ses olarak tanımlanmaktadır. İnsanların fizyolojik ve psikolojik durumunu olumsuz olarak etkileyebilmektedir. Gürültü kirliliğinin sağlık üzerindeki etkileri; duyma bozuklukları, iletişim etkileri, uyku bozuklukları, performans kaybı, gürültüden kaynaklanan rahatsızlık, kardiyovasküler problemler ve çocuklarda zihinsel bozukluklar olarak sıralanabilir [1-6]. Ulaşım kaynaklı gürültü; çevresel gürültü kaynakları arasında en çok maruz kalınan gürültü kaynağıdır. Avrupa'da nüfusun \%40'ından fazlası sağlığı olumsuz etkileyecek seviyede trafik gürültü seviyelerine maruz kalmaktadır [7].

Karayolu gürültüsü tüm dünyada olduğu gibi ülkemizde de gürülttuden etkilenme bakımından büyük sorun teşkil etmektedir. Özellikle konut ve ticari yapılar ile gürülttüye hassas kullanımların birlikte bulunduğu alanlarda nüfus yoğunluğunun fazla olması ve bu alanların şehir merkezlerine bağlantılarının sağlanabilmesi için genelde otoyol çeperlerinde kurulması gürültüden etkilenen kişi sayısının artmasına sebep olmuştur.

Ses, havadaki basınç seviyesinin değişiminin sonucu olarak ortaya çıkar. Ses basınç seviyesi Desibel $(\mathrm{dB})$ olarak ifade edilir. Ölçümlerde genelde insan kulağının duyarlı olduğu frekanslara göre ilişkilendirilmiş olan A-ağırlıklı ses basınç seviyeleri (dB(A)) kullanılmaktadır. Gürültünün insan üzerinde etkisi kaynağın ses şiddetine olduğu kadar gürültüye maruziyetinin süresine de bağlıdır. Bu nedenle uzun süreli gürültü maruziyeti eşdeğer ses seviyesi $\left(\mathrm{L}_{\mathrm{eq}}\right)$ ile ifade edilir. Eşdeğer ses seviyesi verilen bir süre içinde süreklilik gösteren ses basınç seviyesinin ortalama değerini gösterir. Çevre etki analizlerinde, yıllık eşdeğer ses düzeyleri kullanılmaktadır. Çevresel gürültüyü değerlendirme kapsamında $L_{\text {aksam }}$ ve $L_{\text {gag }}$ gürültü göstergeleri olarak kullanılır. $L_{\text {gece, }}$, 23:0007:00 zaman dilimindeki 4 saatlik, $\mathrm{L}_{\text {gag }}$ (gündüz, akşam, gece gürültü seviyesi) ise 24 saatlik A-ağırlıklı uzun dönem ses seviyesi enerji ortalamasını göstermektedir. $\mathrm{L}_{\mathrm{gag}}$ hesaplanma yöntemi Formül (1)'de gösterilmiştir. Akşam ve gece gürültüden etkilenim daha fazla olduğundan $L_{g a g}$ hesaplanmasında akşam ses seviyeleri $5 \mathrm{~dB}(\mathrm{~A})$, gece ses seviyeleri ise $10 \mathrm{~dB}(\mathrm{~A})$ arttırılmıştır.

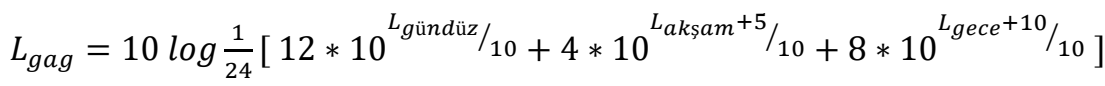

$\mathrm{L}_{\text {gündüz }}=$ 07:00-19:00 saatleri arasındaki 12 saatlik A ağılıklı uzun dönem ses seviyesi ortalamas1

$\mathrm{L}_{\text {gece }}=$ 23:00-07:00 saatleri arasındaki 8 saatlik uzun dönem ses seviyesi ortalamas1

Gürültü, özellikle son on y1llık süreçte, artan trafik düzeyleri ve gürültü kaynaklı sağlık sorunlarına karşı artan farkındalık çerçevesinde en önemli çevresel sorunlardan biri halini almıştır. Bu nedenle Avrupa ve Amerika başta olmak üzere birçok ülkede gürültü kirliliği mevzuat kapsamına alınmış ve buna yönelik ciddi denetimler getirilmiştir. Gürültü kirliliği ülkemizde ilk kez 1986 yılında Çevre Kanunu kapsamında yer almış ve yasaya göre Gürültü Kontrol Yönetmeliği çıkarılmıştır. Bu yönetmelik 2010 yılında Avrupa Birliği mevzuatına eşgüdüm nedeniyle yenilenmiş ve yeni yönetmelik iki yüz elli binden fazla yerleşik nüfusu olan yerleşim alanları ile yılda altı milyondan fazla aracın geçtiği ana karayollarına ait gürültü haritalarının oluşturulması ve gürültüden etkilenen kişi sayısının 
belirtilmesi zorunluluğu getirmiştir [8]. Bu yönetmelik, gürültü haritaları oluşturma konusunda belediyelere yetki ve görev vermiştir. Yönetmeliğe göre ticari yapılar ile gürültüye hassas kullanımların birlikte bulunduğu alanlardan konutların yoğun olarak bulunduğu bölgelerde $\mathrm{L}_{\text {gündüz }} 68 \mathrm{~dB}(\mathrm{~A})^{\prime} \mathrm{y} 1, \mathrm{~L}_{\mathrm{aksam}}$ ise $63 \mathrm{~dB}(\mathrm{~A})^{c} \mathrm{y} 1, \mathrm{~L}_{\text {gece }}$ ise $58 \mathrm{~dB}(\mathrm{~A})^{6} \mathrm{y} 1$ aşmamalıdır. Belirtilen eşik değerlerden daha yüksek gürültüye maruz kalan alanlar için gürültüyü azaltma eylem planları hazırlanması gerekmektedir.

Karayolu ulaşımı gürülttüsü hareket halindeki taşıtlardan kaynaklanmaktadır. Gürültü düzeyi trafik hacmi, trafik kompozisyonu, hız, aracın hızlanma-yavaşlaması ve araç tipine bağlıdır. Trafikteki araçların çıkardığı gürültü seviyeleri Formül (2) kullanılarak elde edilebilir.

$L_{\text {Toplam }}=10 \log \sum_{i=1}^{N} 10^{L_{i} / 10}$

Araç gürültüsünün ise üç temel bileşeni vardır. Bunlar aerodinamik gürültü, motor gürültüsü ve tekerlek-yol kaplaması etkileşim gürülttüsüdür [9]. Artan hızla beraber aerodinamik gürültü de artmaktadır [10]. Mogrovejo ve diğerleri [11] çalışmalarında hızın yaklaşı $16 \mathrm{~km} / \mathrm{saat}$ artı̧̧ıyla ses seviyelerinde $2,5 \mathrm{~dB}(\mathrm{~A})$ 'llk bir artış olduğunu ortaya koymuştur. Ağır araçların da motor gürülttüsü hafif araçlara göre daha fazla olduğu için trafikte ağır araç oranının artı̧̧ı gürültü seviyelerinde de artışa sebep olacaktır. Trafikteki araçların hızlanma ve yavaşlaması da trafik gürültüsünü arttıran bir faktördür [12]. Yol kaplamalarının gürültüye etkisi üzerinde yapılan çalışmalarda ise gözenekli asfaltın yoğun gradasyonlu asfalta göre tekerlek-yol kaplaması gürültüsünü düşürdüğü görülmüştür [13].

Karayolu ulaşım gürültüsünün sağlık üzerine etkileriyle ilgili çalışmalarda $45 \mathrm{~dB}(\mathrm{~A})$ ve üzeri $\mathrm{L}_{\text {gag }}$ seviyelerinin rahatsılzlk [14], $45 \mathrm{~dB}(\mathrm{~A})$ ve üzeri $\mathrm{L}_{\text {gece }}$ seviyelerinin uyku bozuklukları [15] ve $55 \mathrm{~dB}(\mathrm{~A})$ ve üzeri $\mathrm{L}_{\text {gündüz-16 saat }}(7: 00-23: 00$ aras1 eşdeğer ses seviyesi) seviyelerine maruz kalanlarda ise kardiyovasküler hastalık riskinin artacağ 1 gösterilmiştir [16]. Bu bağlamda Avrupa'da ve diğer birçok ülkede gürültü haritaları hazırlanmış, ses seviyeleri sınır değerlerin üzerinde kalan alanlar için eylem planları yapılmıştır. Bu eylem planları çerçevesinde hız sınırlamaları, trafik hacmi ve kompozisyonu (ağır ve hafif araç oranı) düzenlemeleri [12] ile ses emici yol üst yapı tipleri [9] kullanılarak gürültünün azaltılması hedeflenmiş̧ir. Fakat bu değişkenlerin sağlık üzerine olan direkt etkileri henüz ortaya konmamıştır. Bu nedenle, bu çalışmada trafik değişkenleri olan trafik hacmi, trafik kompozisyonu ve trafik hızı ile yol üst yapı tipinin gürültünün sağlık üzerindeki olumsuz etkilerine maruz kalma riski taşıyan kişi sayısına olan etkisi incelenmiştir. Çalışma alanı olarak İstanbul Okmeydanı D-100 karayolu ele alınmış, SoundPlan 6.5 gürültü haritalama programı kullanılarak gürültü haritaları oluşturulmuştur. Öncelikle yol kenarında gürültü ölçümleri yapılmış, elde edilen değerler simüle edilen gürültü seviyeleriyle karşılaştırılmıştır. Daha sonra bu karayolundaki değişik trafik hacmi, kompozisyonu ve hızı ile değişik yol üst yapı tipleri için rahatsızlık, uyku bozukluğu ve kardiyovasküler hastalık riski altında olan kişi sayıları karş̧laştırılmıştır. Bu sonuçlara dayanarak karayolu gürültü seviyelerinin azaltılması için hangi yöntemlerin kullanılabileceği incelenmiştir. 
Trafik Gürültüsünü Etkileyen Faktörlerin SoundPlan 6.5 Programı ile İncelenmesi

\section{METODOLOJI}

\subsection{Calıșma Alanının Tanımlanması}

$\mathrm{Bu}$ araştırmada, çalışma alanı olarak Okmeydanı D-100 Otoyolu seçilmiştir. Bu otoyol Şişli İlçesi Halil Rıfat Paşa Mahallesi ve Kağıthane İlçesi Talatpaşa Mahallesi'ni birbirinden ayırmakta olup 2 şeridi metrobüs hattına ait, 3 şeridi Haliç-Mecidiyeköy yönünde, 3 şeridi de Mecidiyeköy-Haliç yönünde olmak üzere toplamda 8 şeritlidir. Yol üst yapı malzemesi taş mastik asfalttır ve yol Talatpaşa mahallesinden kot olarak yüksekte kalmaktadır. Çalışma alanı toplamda yaklaşım 720 m olup Şekil 1'de gösterilmiştir.

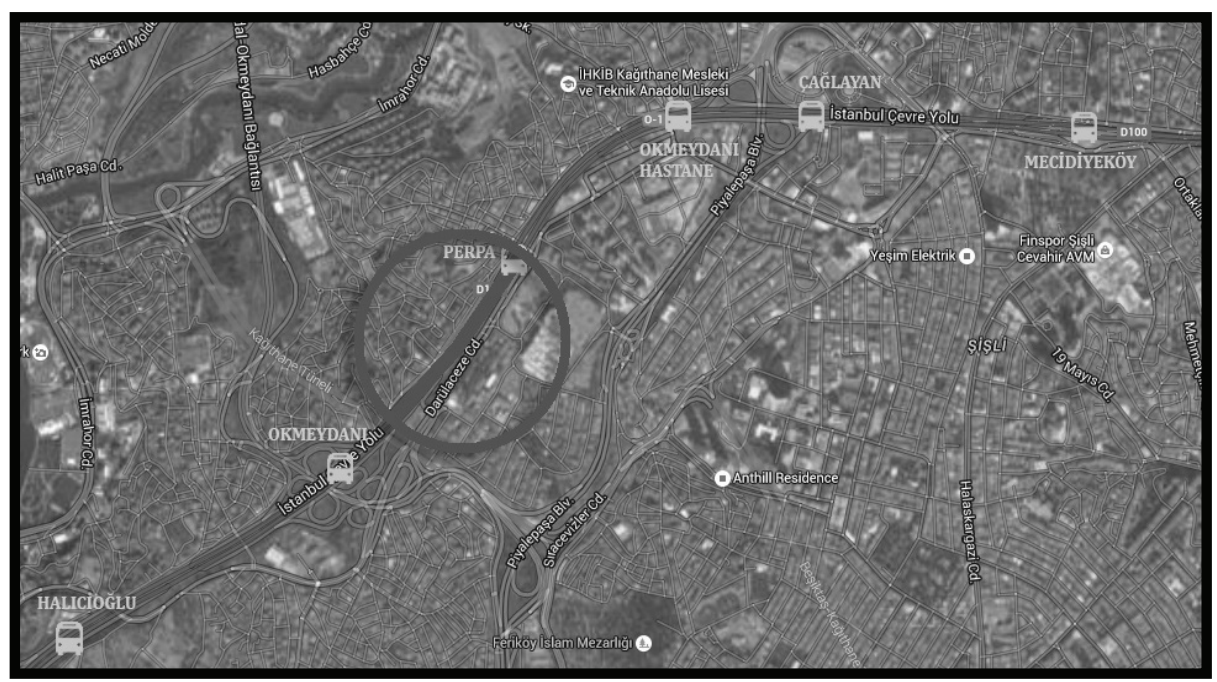

Şekil 1. Halil Rıfatpaşa ve Talatpaşa Mahalleri’nin Uydu Görünümü

\subsection{Yol Kenarı Gürültü Ölçümleri}

Arazi gürülttü ölçümleri, gürültü haritalamasında kaynak gürültü seviyesini belirlemede, kalibre etmede ve alıcı gürültü seviyelerini doğrulamada kullanılmaktadır [17]. SoundPlan 6.5 programında da gürültü haritaları, incelenen yoldan geçen araç sayıları ve hızları kullanılarak oluşturulabileceği gibi yol kenarında yapılan arazi ölçümleriyle belirlenen yol gürültü seviyeleri programa aktarılarak da elde edilebilir. Bu çalışmada da ölçüm sonuçlarını doğrulamak ve gerektiğinde program girdilerini (yansıma, kırınım, meteorolojik veriler) kalibre etmek amacıyla yol kenarında ölçümler yapılmıştır. Gürültü haritaları, hem trafik verileri kullanılarak hem de ölçülen yol gürültü seviyesi manuel olarak programa girilerek oluşturulmuştur.

D-100 otoyolunun Okmeydanı mevkii trafik gürültü seviyeleri, rüzgarın $5 \mathrm{~m} / \mathrm{s}$ 'nin altında olduğu ve yağışın olmadığı zamanlarda, yolun her iki tarafinda 5 olmak üzere 10 ayrı noktasında ölçüm yapılarak belirlenmiştir. Gündüz zaman diliminde (07:00-19:00 saatleri arasında) 70 adet, akşam zaman diliminde (19:00-23:00 saatleri arasında) 30 adet, gece zaman diliminde (23:00-07:00 saatleri arasında) ise 60 adet olmak üzere toplam 160 adet manuel ölçüm yapılmıştır. Ölçümler TS 9315 (ISO 1996-1) ve TS 9798 (ISO 1996-2) 
Standartlarına göre yapılmış olup, ölçümlerde Brüel\&Kjaer 2250 ses seviyesi ölçer kullanılmıştır. Ölçümlerde mikrofon seviyesi yerden 1,2 m yükseklikte olup mikrofon yol kenarı bariyerinin arkasına yerleştirilmiştir. Ölçümlerden önce ve sonra mikrofon kalibre edilmiştir. Ölçüm yapılan noktalar Şekil 2'de, ölçümün nasıl yapıldığı ise Şekil 3'de gösterilmiştir.

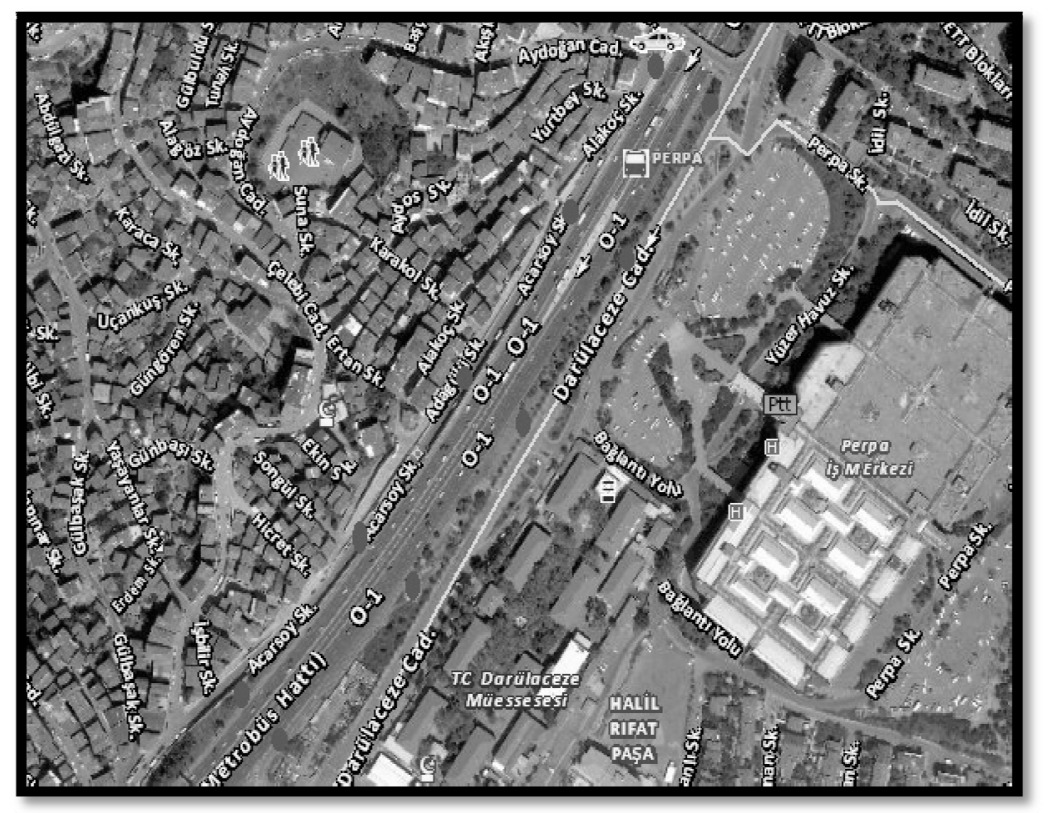

Şekil 2. Yol Kenarı Ölçüm Noktaları

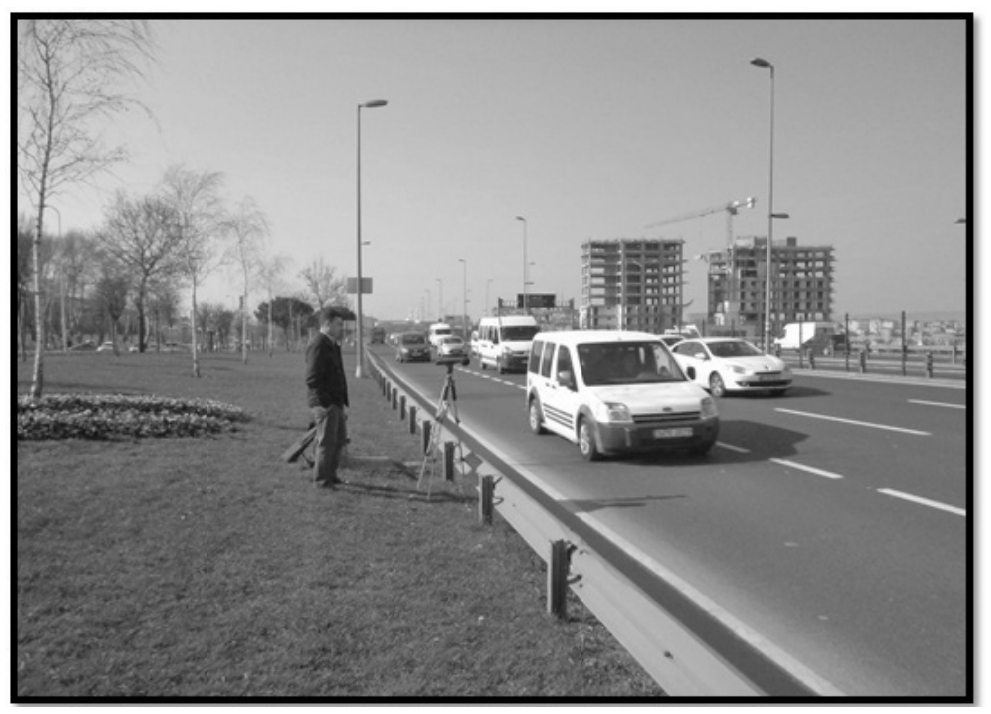

Şekil 3. Yol Kenarı Gürültü Ölçümü 


\subsection{Gürültü Haritası Verileri}

Çevresel Gürültünün Kontrolü ve Yönetimi Yönetmeliğine uygun bir program olduğundan bu çalışmada gürültü haritaları SoundPlan 6.5 kullanılarak oluşturulmuştur. Gürültü haritaları $\mathrm{L}_{\text {gag }}$ ve $\mathrm{L}_{\text {gece }}$ olarak $55 \mathrm{~dB}(\mathrm{~A})$ ve üzerinde, $65 \mathrm{~dB}(\mathrm{~A})$ ve üzerinde, $75 \mathrm{~dB}(\mathrm{~A})$ ve üzerinde gürültü seviyelerine maruz kalan konut, okul, hastane ve kişi sayısını vermektedir. SoundPlan dünyada gürültü haritalarının oluşturulmasında kullanılan en yaygın program olduğu gibi ülkemizde de birçok kamu kuruluşu tarafından kullanılmaktadır.

Şişli İlçesi Halil Rıfat Paşa Mahallesi ve Kağıthane İlçesi Talatpaşa Mahallesi'ne ait dijital halihazır haritalar İstanbul Büyükşehir Belediyesi (IBB) Harita Müdürlüğü’nden alınmış, bu dijital haritalar SoundPlan 6.5 programına işlenmiştir. SoundPlan programına AutoCAD, GIS ve Microstation gibi programlardan dijital harita verileri girilebilmektedir. Çalışma yapılan mahaller için nüfus bilgileri Nüfus Müdürlüğü'nden alınarak Halil Rıfatpaşa Mahallesi'nde 2369 kişinin yaşadığı, Talatpaşa Mahallesi'nde ise 34392 kişinin yaşadığı belirlenmiştir. Bu veriler de programa girdi olarak işlenmiştir.

Trafik bilgileri kullanılarak oluşturulacak gürültü haritaları için nüfus ve harita bilgilerinin yanı sıra Okmeydanı D-100 üzerindeki yıllık ortalama araç sayısı, araç kompozisyonu ve hızı gibi verilere de ihtiyaç duyulmaktadır. Bu veriler, İBB Trafik Müdürlüğ̈̈’ne ait D-100 Karayolu Mecidiyeköy-Haliç yönünde bulunan 296 numaralı sensörden ve HaliçMecidiyeköy yönünde bulunan 297 numaralı sensörden elde edilmiştir. Bu sensörlere ait yıllık saatte geçen ortalama ağır (metrobüs hariç) ve hafif araç sayıları ve yıllık bazda saatlik ortalama hızlar gündüz (7:00- 19:00 saatleri arası), akșam (19:00-23:00 saatleri arası) ve gece (23:00-7:00 saatleri arası) zaman dilimleri için sırasıyla Şekil 4 ve Şekil 5'de verilmiştir. Boğaziçi Köprüsü’nden ağır araç geçişi yasak olduğu için D-100 karayolunda ağır araç trafiğginin oldukça düşük olduğu görülmektedir. Haliç - Mecidiyeköy yönünde trafik hacminin Mecidiyeköy- Haliç Yönüne göre yüzde 10 ile yüzde 26 arasında daha düşük olduğu bu bağlamda da Haliç- Mecidiyeköy yönü trafik hızının diğer yöne göre yüzde 3 ile yüzde 9 arasında daha fazla olduğu görülmektedir.

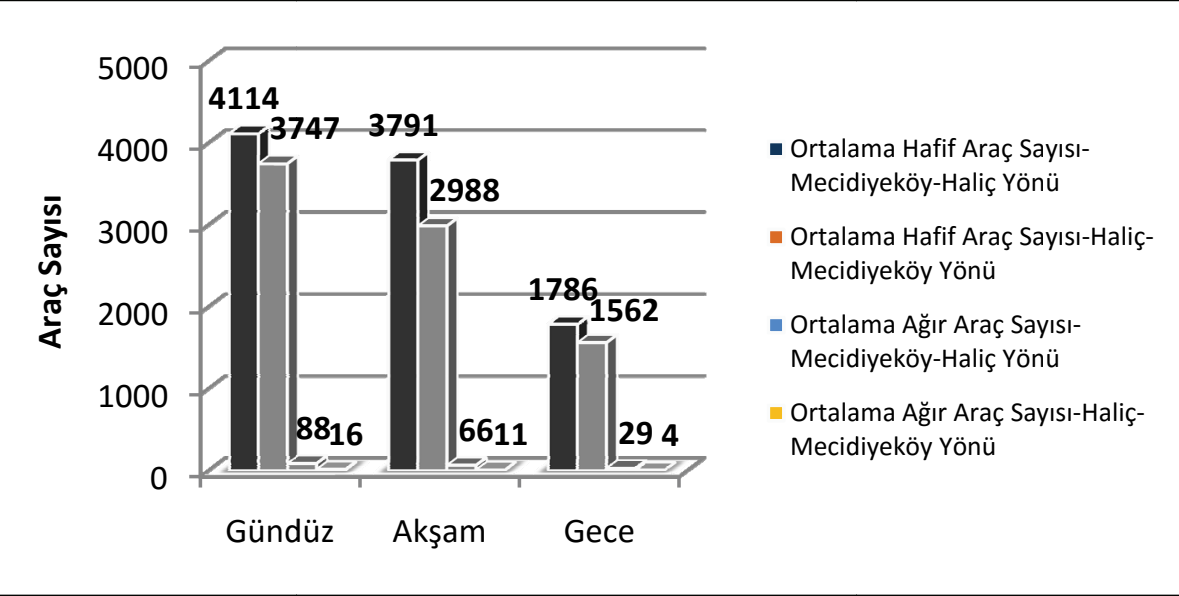

Şekil 4. Yıllık Saatte Geçen Ortalama Hafif ve Ağır Araç Sayısı 


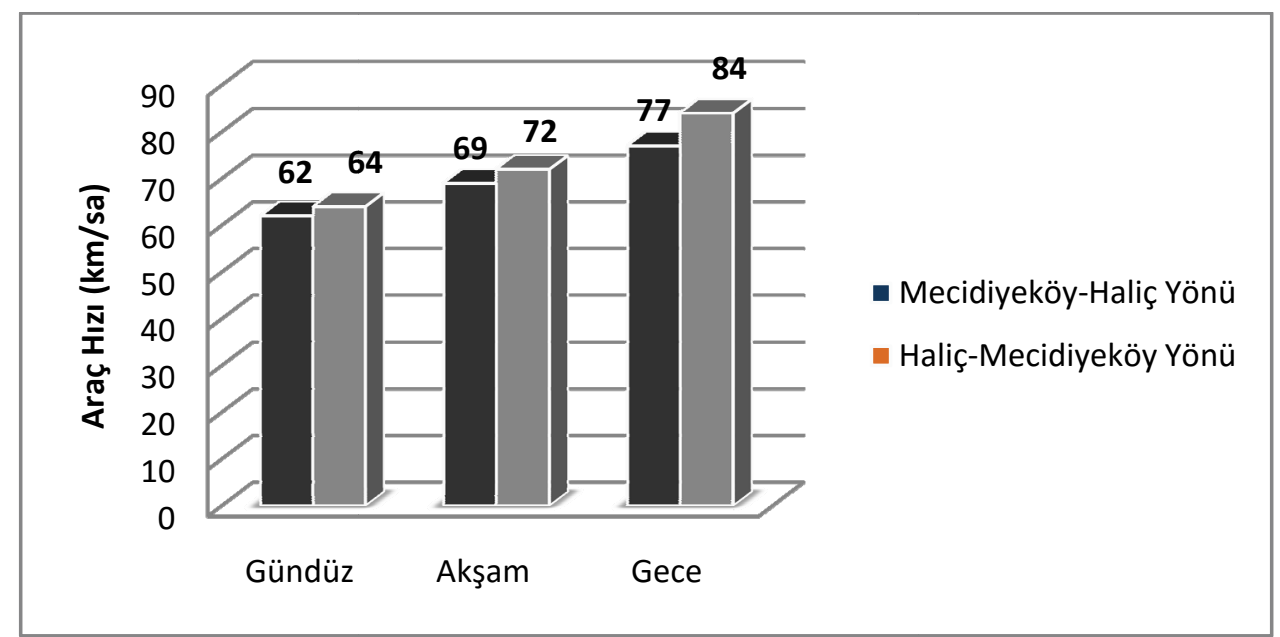

Şekil 5. Yıllık Bazda Saatlik Ortalama Hız

Şekil 6'da ise metrobüs hattının Mecidiyeköy-Haliç ve Haliç-Mecidiyeköy yönünden geçen otobüs sayısı gösterilmektedir. Şekil 6'dan görülebileceği üzere metrobüs D-100 yolundaki ağır araç trafiğinin büyük kısmını, yaklaşık yüzde 65 'ini oluşturmaktadır. Bu bağlamda gürültü seviyeleri üzerine etkisinin büyük olması beklenmektedir. Metrobüs hattından geçen araçların hızını algılayan bir sensör bulunmadığından söz konusu hatta yapılan incelemelere istinaden bu araştırmada metrobüs hattında çalışan araçların hızı saatte ortalama $40 \mathrm{~km}$ olarak alınmıştır.

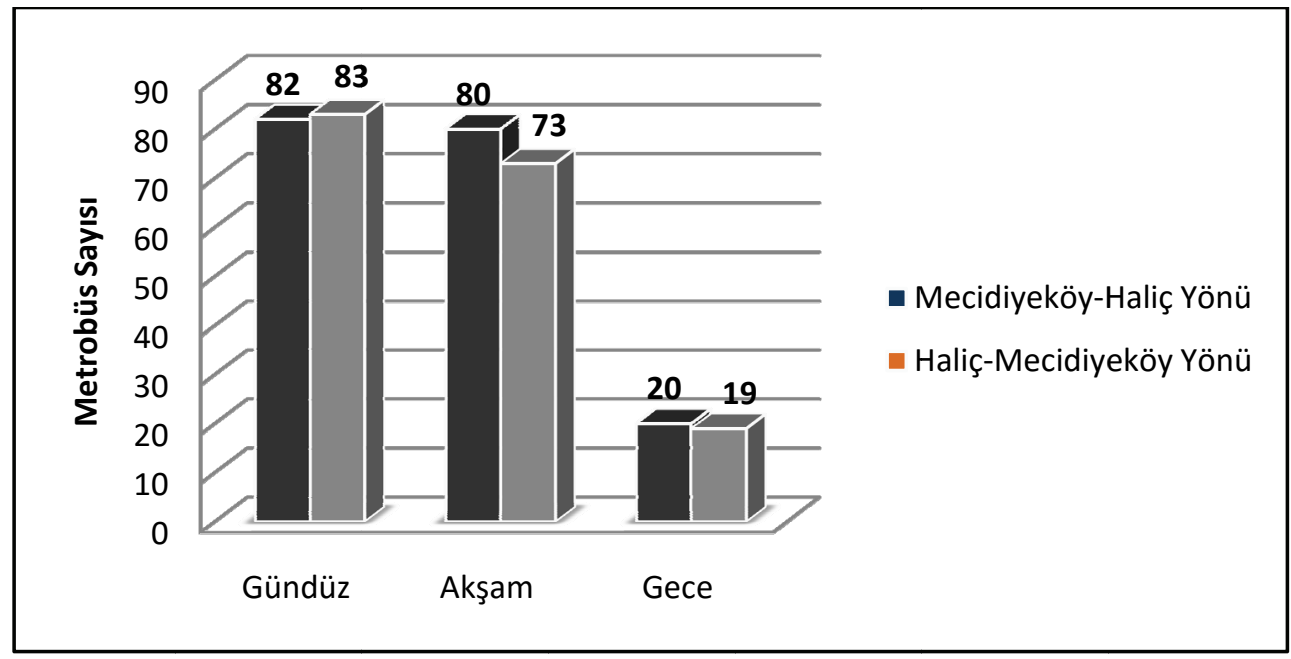

Şekil 6. Saatte Geçen Ortalama Metrobüs Sayısı 
İBB Trafik Müdürlüğü'nden elde edilen yukarıda gösterilmiş olan veriler SoundPlan6.5 programına girilerek öncelikle mevcut duruma ait referans gürültü haritaları oluşturulmuştur. SoundPlan 6.5 programı yol üstyapısının asfalt beton ya da gözenekli asfalt şeklinde seçilmesine izin vermektedir. D-100 karayolunda yol üst yapısı taş mastik asfalttır. Bu üstyapı tipine en yakın seçenek olarak asfalt beton seçilmiştir. Referans gürültü haritaları yol kenarında yapılan ölçümlerle karşılaştııılmıştır.Daha sonra trafik değişkenlerinin etkilerini incelemek amacıyla trafik hacmi $\% 1, \% 5, \% 10$ oranında arttırılarak,trafik ortalama hızı $5 \mathrm{~km} / \mathrm{saat}$ ve $10 \mathrm{~km} / \mathrm{saat}$ değiştirilerek ve metrobüs hesaba katılmadan gürültü haritaları hazırlanmış ve rahatsızlık, uyku bozuklukları ve kardiyovasküler hastalık riskleri referans haritalardan elde edilen hastalık riskleriyle karşılaştırılmıştır. Ayrıca, araştırmalar gözenekli asfaltın yoğun gradasyonlu asfalta göre ses seviyelerini ortalama olarak $3 \mathrm{~dB}(\mathrm{~A})$ kadar düşürebildiğini göstermiştir [9]. Benzer şekilde yol üstyapısı gözenekli asfalt seçilerek de gürültü haritaları oluşturulmuş ve hastalık riskleri referans haritadan elde edilen sonuçlarla kıyaslanmıştır.

\section{DEĞERLENDİRMELER}

SoundPlan 6.5 programı ile hazırlanan haritalar $\mathrm{L}_{\text {gag }}$ ve $\mathrm{L}_{\text {gece }}$ değerleri için $55-65 \mathrm{~dB}(\mathrm{~A}), 65$ $75 \mathrm{~dB}(\mathrm{~A})$ ve $75 \mathrm{~dB}(\mathrm{~A})$ ve üstü gürültüye maruz kalan konut, okul, hastane ve kişi sayısını göstermektedir. İBB Trafik Müdürlügü̈'nden elde edilen mevcut ağır ve hafif araç sayıları ve hızları ile saatte geçen ortalama metrobüs sayısı girilerek ve yol tipi olarak düz (mastik veya beton) asfalt seçilerek oluşturulan gürültü haritaları referans haritalar olarak kabul edilmiştir. $\mathrm{L}_{\mathrm{gag}}$ ve $\mathrm{L}_{\text {gece }}$ değerleri için oluşturulmuş referans haritalar sırasıyla Şekil 7 ve Şekil 8'de verilmiştir. Referans $\mathrm{L}_{\text {gag }}$ haritasına göre $55 \mathrm{~dB}(\mathrm{~A})$ 'dan fazla gürültüye maruz kalan kişi sayısı 4144, $65 \mathrm{~dB}(\mathrm{~A})$ 'dan fazla gürültüye maruz kalan kişi sayıs1 905, 75 $\mathrm{dB}(\mathrm{A})$ 'dan fazla gürültüye maruz kalan kişi sayısı ise 98 bulunmuştur. Ayrıca referans ( $\mathrm{L}_{\text {gag }}$ ) haritasına göre $55 \mathrm{~dB}(\mathrm{~A})$ 'dan fazla gürültüye maruz kalan konut sayısı 277,65 $\mathrm{dB}(\mathrm{A})$ 'dan fazla gürültüye maruz kalan konut sayısı $56,75 \mathrm{~dB}(\mathrm{~A})$ 'dan fazla gürülttïye maruz kalan konut sayısı ise 4 bulunurken bölgede hiçbir okul ve hastanenin $55 \mathrm{~dB}(\mathrm{~A})$ 'dan fazla gürültüye maruz kalmadığ görülmüsstür. Referans $\mathrm{L}_{\text {gece }}$ haritasına göre $55 \mathrm{~dB}(\mathrm{~A})$ 'dan fazla gürültüye maruz kalan kişi sayısı 1476, $65 \mathrm{~dB}(\mathrm{~A})$ 'dan fazla gürültüye maruz kalan kişi sayısı 219, $75 \mathrm{~dB}(\mathrm{~A})$ 'dan fazla gürültüye maruz kalan kişi sayısı ise 4 bulunmuştur. Ayrıca referans $\left(\mathrm{L}_{\text {gece }}\right.$ ) haritaya göre $55 \mathrm{~dB}(\mathrm{~A})$ 'dan fazla gürültüye maruz kalan konut sayısı 97, $65 \mathrm{~dB}(\mathrm{~A})$ 'dan fazla gürültüye maruz kalan konut sayıs1 10 bulunmuştur ve referans $\mathrm{L}_{\text {gece }}$ haritasına göre bölgede hiçbir okul ve hastanenin $55 \mathrm{~dB}(\mathrm{~A})$ 'dan fazla gürültüye maruz kalmadığı görülmüştür.

Kritik gürültü seviyeleri rahatsızlık riski için $45 \mathrm{~dB}(\mathrm{~A})$ ve üzeri $\mathrm{L}_{\text {gag }}$ değerleri, uyku bozuklukları için ise $45 \mathrm{~dB}(\mathrm{~A})$ ve üzeri $\mathrm{L}_{\text {gece }}$ değerleridir. Fakat gürültü haritaları $55 \mathrm{~dB}(\mathrm{~A})$ ve üzeri gürültü seviyelerini gösterdiği için rahatsızlık ve uyku bozukluğu riski $55 \mathrm{~dB}(\mathrm{~A})$ ve üzeri gürültü seviyelerine maruz kalan kişiler için incelenmiştir. Kardiyovasküler hastalıklar için kritik gürültü değeri $\mathrm{L}_{\text {gündüz-16 saat }}$ için $55 \mathrm{~dB}(\mathrm{~A})$ ve üzeridir. Fakat gürültü haritaları sadece $L_{\text {gag }}$ ve $L_{\text {gece }}$ değerlerini vermektedir. Genelde $L_{\text {day-16sat }}$ değerlerinin $L_{\text {gag }}$ değerlerinin $2 \mathrm{~dB}(\mathrm{~A})$ kadar üzerinde olduğu görülmüştür [18]. Bu nedenle de kardiyovasküler hastalıklar için kritik değer olarak $57 \mathrm{~dB}(\mathrm{~A})$ ve üzeriL gag gürültü seviyeleri alınmıştır. Fakat gürültü haritaları, $10 \mathrm{~dB}(\mathrm{~A})$ aralıklarla $55 \mathrm{~dB}(\mathrm{~A})$ ve üzeri gürültü seviyelerine maruziyeti verdiği için kardiyovasküler hastalık riski için kritik değer olarak $55 \mathrm{~dB}(\mathrm{~A})$ ve üzeri $\mathrm{L}_{\mathrm{gag}}$ seviyeleri incelenmiştir. 
Aybike ÖNGEL, Fatih SEZGIN

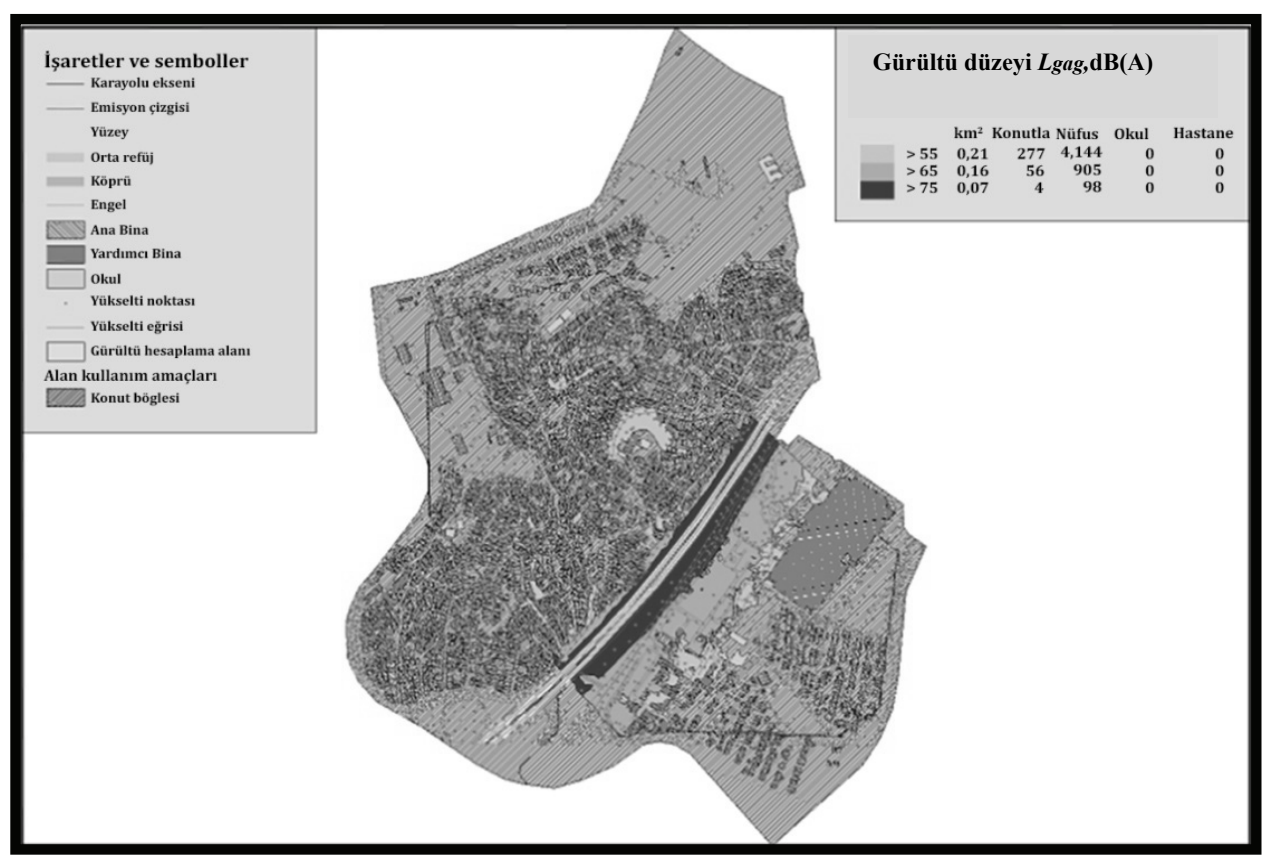

Şekil 7. Referans harita $\left(L_{\text {gag }}\right)$

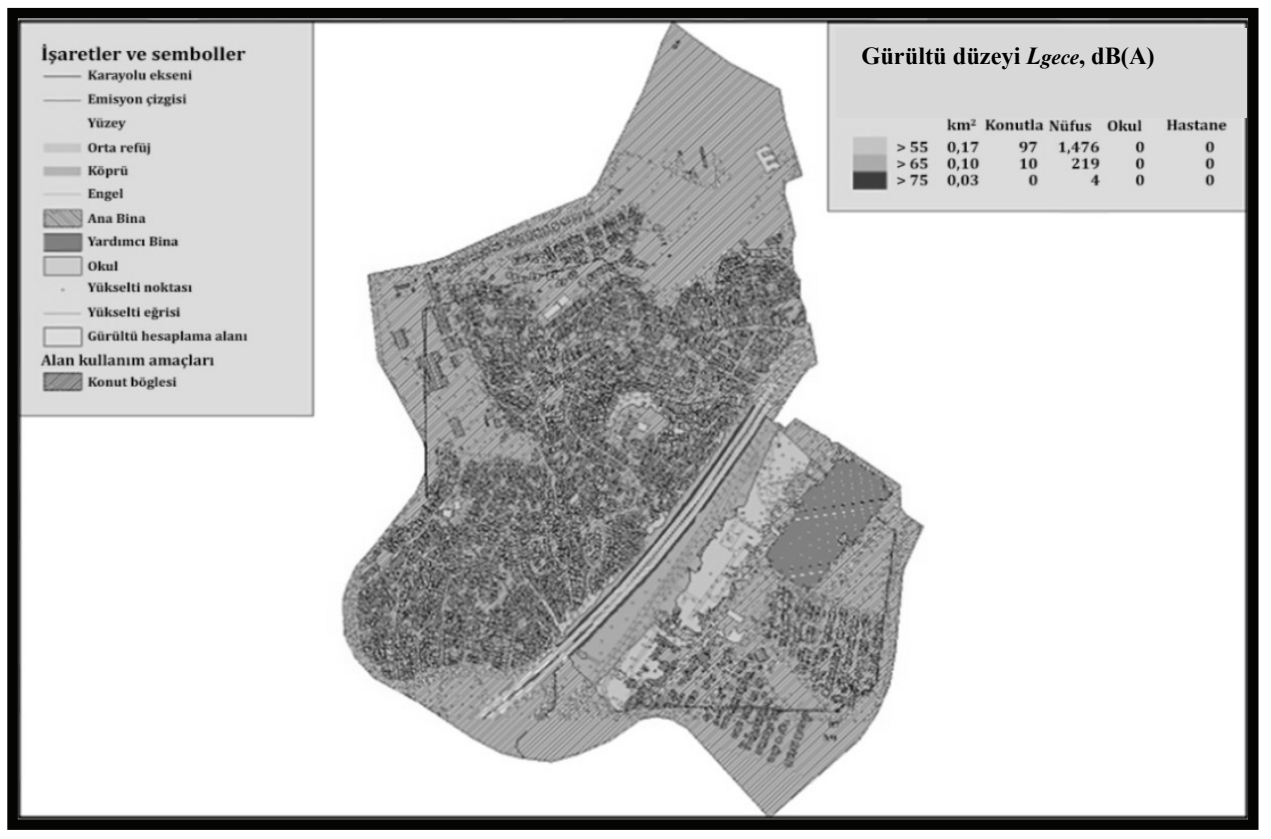

Şekil 8. Referans harita ( $\left.L_{\text {gece }}\right)$ 
Yukarıda belirtilen kritik değerler göz önüne alındığında referans haritalardan elde edilen sonuçlara göre Halil Rıfatpaşa ve Talatpaşa Mahalleri'nde yaşayan nüfusun yaklaşık yüzde $11^{\prime} \mathrm{i}, 55 \mathrm{~dB}(\mathrm{~A})$ ve üzeri $\mathrm{L}_{\mathrm{gag}}$ seviyelerine maruz kalmakta, bu bağlamda da rahatsızlık ve kardiyovasküler hastalık riski taşımaktadır. Gene bu bölgedeki nüfusun yaklaşık yüzde 4'ü, $55 \mathrm{~dB}(\mathrm{~A})$ ve üzeri $\mathrm{L}_{\text {gece }}$ seviyelerine maruz kalmakta ve bu nedenle de uyku bozukluğu riski taşımaktadır.

Gürültü haritalarını doğrulamak veya gerektiğinde sonuçları kalibre etmek için yol kenarında yapılan gürültü ölçüm sonuçları haritadan elde edilen kaynak gürültüsüyle kıyaslanmıştır. Tablo 1'de yol kenarında yapılan gürültü ölçümlerinin gündüz, akşam ve gece zaman dilimleri için ortalama değerleri ve standart saplamaları verilmiştir. Stratejik gürültü haritalamasında, gürültü değerlerinin ölçülen değerlerle kıyaslanmasında standart sapma $5 \mathrm{~dB}(\mathrm{~A})$ 'dır [19]. Bu bağlamda, yapılan ölçümlerin standart sapmasının stratejik haritalarda görülen standart sapmanın çok daha altında kaldığı görülmektedir. Ölçüm sonuçları, gürülttü haritalarından elde edilen $\mathrm{L}_{\text {gece }}$ ve $\mathrm{L}_{\mathrm{gag}}$ yol gürültüsü (kaynak gürültüsü) değerleri ile karşılaştırılmıştır. Gürültü haritasından elde edilen yol gürültü seviyeleri, ölçüm sonuçlarından $\mathrm{L}_{\text {gece }}$ için yaklaşık $6 \mathrm{~dB}(\mathrm{~A})$, $\mathrm{L}_{\text {gag }}$ için yaklaşık $5 \mathrm{~dB}(\mathrm{~A})$ daha fazladır. Stratejik gürültü haritalarındaki $5 \mathrm{~dB}(\mathrm{~A})$ 'llk ortalama standart sapma göz önüne alındığında, ölçüm ve simülasyon gürültü seviyeleri arasındaki fark istatiksel olarak anlamlı bulunmamıştır $(\mathrm{p}<0,05)$. Bu nedenle gürültü haritalarında kullanılan girdilere herhangi bir kalibrasyon faktörü uygulanmamıştır.

Tablo 1. Referans Haritaları ve Ölçüm Sonuçlarına Göre D-100 Gürültü Seviyeleri

\begin{tabular}{|c|c|c|c|c|}
\hline \multirow{2}{*}{$\begin{array}{c}\text { Gürülttü } \\
\text { İndikatörleri }\end{array}$} & \multicolumn{2}{|c|}{ Ölçüm Sonuçları } & $\begin{array}{c}\text { Referans Harita } \\
\text { Sonuçları }\end{array}$ & \multirow{2}{*}{ Fark } \\
\cline { 2 - 4 } & Ortalama & $\begin{array}{c}\text { Standart } \\
\text { Sapma }\end{array}$ & Ortalama & \\
\hline $\begin{array}{c}\mathrm{L}_{\text {gündüz }} \\
(07: 00-19: 00), \mathrm{dB}(\mathrm{A})\end{array}$ & 82,3 & 3,0 & - & - \\
\hline $\begin{array}{c}\mathrm{L}_{\text {aksam }} \\
(19: 00-23: 00), \mathrm{dB}(\mathrm{A})\end{array}$ & 81,3 & 3,8 & - & - \\
\hline $\begin{array}{c}\mathrm{L}_{\text {gece }} \\
(23: 00-07: 00), \mathrm{dB}(\mathrm{A})\end{array}$ & 81,9 & 1,4 & 76 & 5,9 \\
\hline $\mathrm{L}_{\mathrm{gag}}, \mathrm{dB}(\mathrm{A})$ & 86,2 & - & 81 & 5,2 \\
\hline
\end{tabular}

Referans haritalara ek olarak ölçüm sonuçlarından elde edilen değerler yol trafik gürültüsü (kaynak gürültüsü) olarak SoundPlan programına girilerek de gürültü haritaları hazırlanmıştır. Tablo 2'de referans haritaların etki analiz sonuçları, ölçümlerle oluşturulan haritaların etki analiz sonuçlarıyla karşılaştırılmıştır. Gürültü etki alanı $\mathrm{km}^{2}$ ve konut, nüfus, okul, hastane sayısı olarak gösterilmiştir. Tablodan görülebileceği üzere, D-100 karayolu gürülttü seviyeleri için ölçüm sonuçları ve referans harita sonuçları arasında istatiksel olarak anlamlı bir fark olmasa da ölçüm değerleriyle elde edilen haritaya göre gürültüden etkilenen alan $\left(\mathrm{km}^{2}\right)$, konut sayısı veya nüfus değerleri, referans harita değerlerinin $20 \%$ 'si ile 90\%'ı arasında değişmektedir. Bu da ölçüm sonuçlarıyla, gürültü simülasyonu yapılarak elde edilen farkın oldukça büyük olduğunu göstermektedir. 
Tablo 2. Gürültü Etki Analiz Karşılaştırması

\begin{tabular}{|l|l|l|l|l|l|l|}
\hline Haritalar & $\begin{array}{l}\text { Gürültü } \\
\text { İndikatörleri }\end{array}$ & $\begin{array}{l}\text { Gürültü } \\
\text { Seviyeleri, } \\
\mathbf{d B ( A )}\end{array}$ & $\mathbf{k m}^{\mathbf{2}}$ & $\begin{array}{l}\text { Konut } \\
\text { Sayısı }\end{array}$ & Nüfus & $\begin{array}{l}\text { Okul ve } \\
\text { Hastane } \\
\text { Sayısı }\end{array}$ \\
\hline \multirow{4}{*}{$\begin{array}{l}\text { Referans } \\
\text { Harita }\end{array}$} & $>55$ & 0,17 & 97 & 1476 & 0 \\
\cline { 2 - 7 } & $\mathrm{L}_{\text {gece }}$ & $>65$ & 0,10 & 10 & 219 & 0 \\
\cline { 2 - 7 } & & $>75$ & 0,03 & 0 & 4 & 0 \\
\cline { 2 - 7 } & $\mathrm{L}_{\mathrm{gag}}$ & $>55$ & 0,21 & 277 & 4144 & 0 \\
\cline { 2 - 7 } & & $>65$ & 0,16 & 56 & 905 & 0 \\
\cline { 2 - 7 } & & $>75$ & 0,07 & 4 & 98 & 0 \\
\hline \multirow{4}{*}{$\begin{array}{l}\text { Ollçümlerle } \\
\text { Harita }\end{array}$} & $\mathrm{L}_{\text {gece }}$ & $>55$ & 0,144 & 42 & 699 & 0 \\
\cline { 2 - 7 } & & $>65$ & 0,058 & 2 & 72 & 0 \\
\cline { 2 - 7 } & & $>75$ & 0,002 & 0 & 0 & 0 \\
\cline { 2 - 7 } & $\mathrm{L}_{\text {gag }}$ & $>55$ & 0,18 & 125 & 1911 & 0 \\
\cline { 2 - 7 } & & $>65$ & 0,11 & 18 & 349 & 0 \\
\cline { 2 - 7 } & & $>75$ & 0,04 & 0 & 7 & 0 \\
\hline
\end{tabular}

Şekil 9'da araç hızlarının referans değerlere göre $5 \mathrm{~km} / \mathrm{saat}$ arttırıldı̆̆ ve azaltıldı̆̆ durumlarda gürültüden etkilenen kişi sayısının değişimi gösterilmektedir. Trafik hızı 5 $\mathrm{km} /$ saat arttığında $55 \mathrm{~dB}(\mathrm{~A})$ ve üzeri $\mathrm{L}_{\text {gag }}$ gürültü seviyesine maruz kalan kişi sayısı yüzde 8,5 artarken, $55 \mathrm{~dB}(\mathrm{~A})$ ve üzeri $\mathrm{L}_{\text {gece }}$ gürültü seviyelerine maruz kalan kişi sayısının yaklaşık yüzde 8 arttığı görülmüştür. Araç hızlarını $5 \mathrm{~km} /$ saat azalttığımızda $55 \mathrm{~dB}(\mathrm{~A})$ ve üzeri $\mathrm{L}_{\text {gag }}$ gürültü seviyesine maruz kalan kişi sayısının yaklaşık yüzde 7,5 azaldığı, 55 $\mathrm{dB}(\mathrm{A})$ ve üzeri $\mathrm{L}_{\text {gece }}$ gürültü seviyelerine maruz kalan kişi sayısının ise yaklaşık yüzde 9,5 azaldığı görülmüştür. Araç hızlarını $10 \mathrm{~km} /$ saat azalttığımızda ise $55 \mathrm{~dB}(\mathrm{~A})$ ve üzeri $\mathrm{L}_{\mathrm{gag}}$ gürültü seviyesine maruz kalan kişi sayısının yaklaşık yüzde 14,5 azaldığı, $55 \mathrm{~dB}(\mathrm{~A})$ ve üzeri $\mathrm{L}_{\text {gece }}$ gürültü seviyelerine maruz kalan kişi sayısının ise yaklaşık yüzde 18,5 azaldığ görülmüştür. Bu bağlamda, rahatsızlık ve kardiyovasküler hastalık riski için kritik değeri 55 $\mathrm{dB}(\mathrm{A})$ ve üzeri $\mathrm{L}_{\text {gag }}$ alındığında her $5 \mathrm{~km} /$ saatlik hız artışıyla rahatsızlık ve kardiyovasküler hastalık riski taşıyan kişi oranının yaklaşık yüzde 7-8 arttığı, uyku bozukluğu için kritik değer $55 \mathrm{~dB}(\mathrm{~A})$ ve üzeri $\mathrm{L}_{\text {gece }}$ alındığında ise uyku bozukluğu riski taşıyanların sayısının yaklaşık yüzde 8-9 oranında arttığı görülmektedir.

Şekil 10'da araç sayılarının referans değerlere göre yüzde 1, yüzde 5 ve yüzde 10 arttırıldığında $55 \mathrm{~dB}(\mathrm{~A})$ ve üzeri gürültüye maruz kalan kişi sayısındaki değişim gösterilmektedir. Verilen grafiğe göre araç sayılarının yüzde 1 , yüzde 5 ve yüzde 10 arttırıldığında $55 \mathrm{~dB}(\mathrm{~A})$ ve üzeri $\mathrm{L}_{\text {gece }}$ seviyelerine maruz kalan kişi sayısı sırasıyla yüzde 0,4 , yüzde 4 ve yüzde 6 oranında; $55 \mathrm{~dB}(\mathrm{~A})$ ve üzeri $\mathrm{L}_{\text {gag }}$ seviyelerine maruz kalan kişi sayısı sırasıyla yüzde 1, yüzde 4 ve yüzde 7 oranında artmaktadır. Bu bağlamda yıllık yüzde 1'lik trafik büyümesi kritik gürültü seviyelerine maruz kalan kişi sayısında önemli bir etki yapmamakla beraber, yüzde 5'lik ve yüzde 10'luk trafik büyümesinin ise rahatsızlık, uyku bozukluğu ve kardiyovasküler hastalık riskini sırasıyla yüzde 4 ve yüzde 6-7 civarında arttırdığı görülmektedir. 
Trafik Gürültüsünü Etkileyen Faktörlerin SoundPlan 6.5 Programı ile İncelenmesi

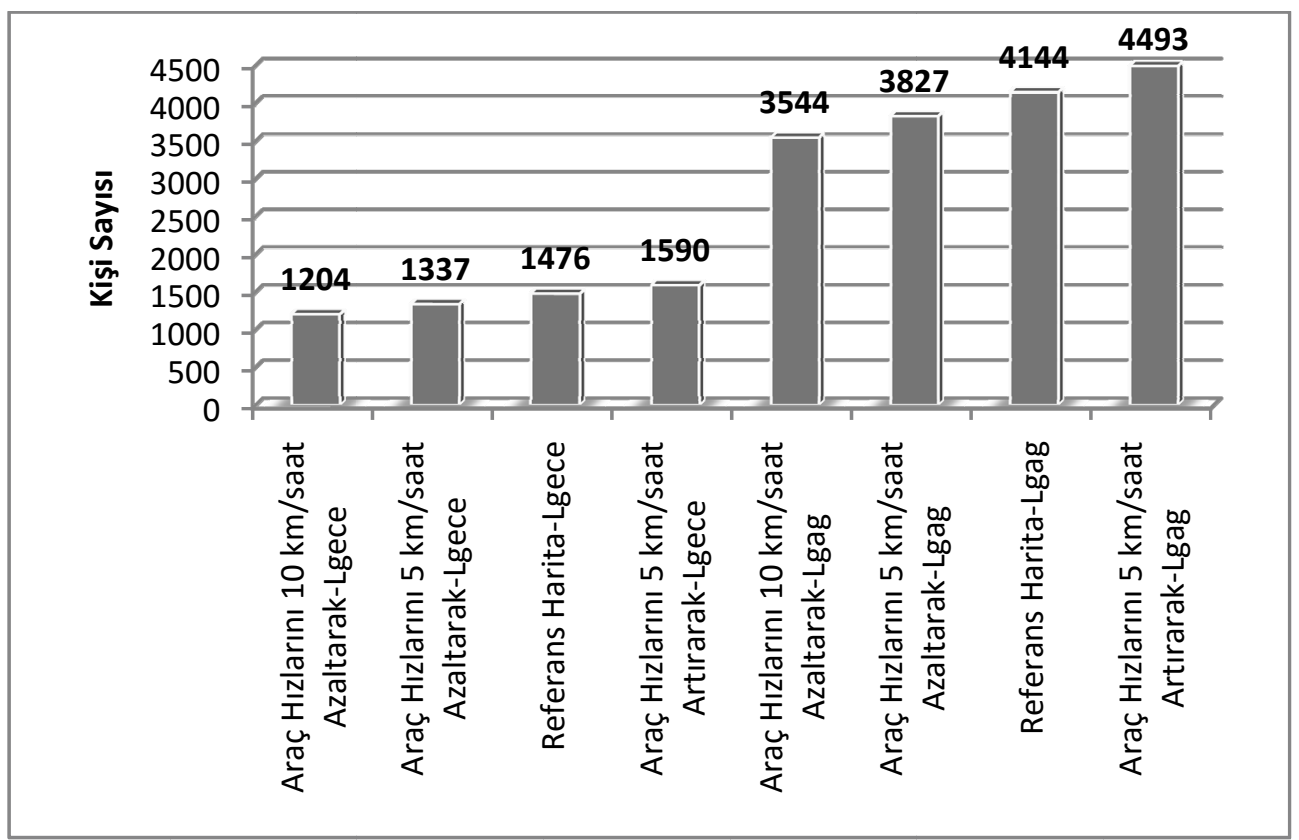

Şekil 9. Değişik araç hızları için $55 d B(A)$ 'nın üzerinde gürültü seviyelerine maruz kalan kişi sayısı

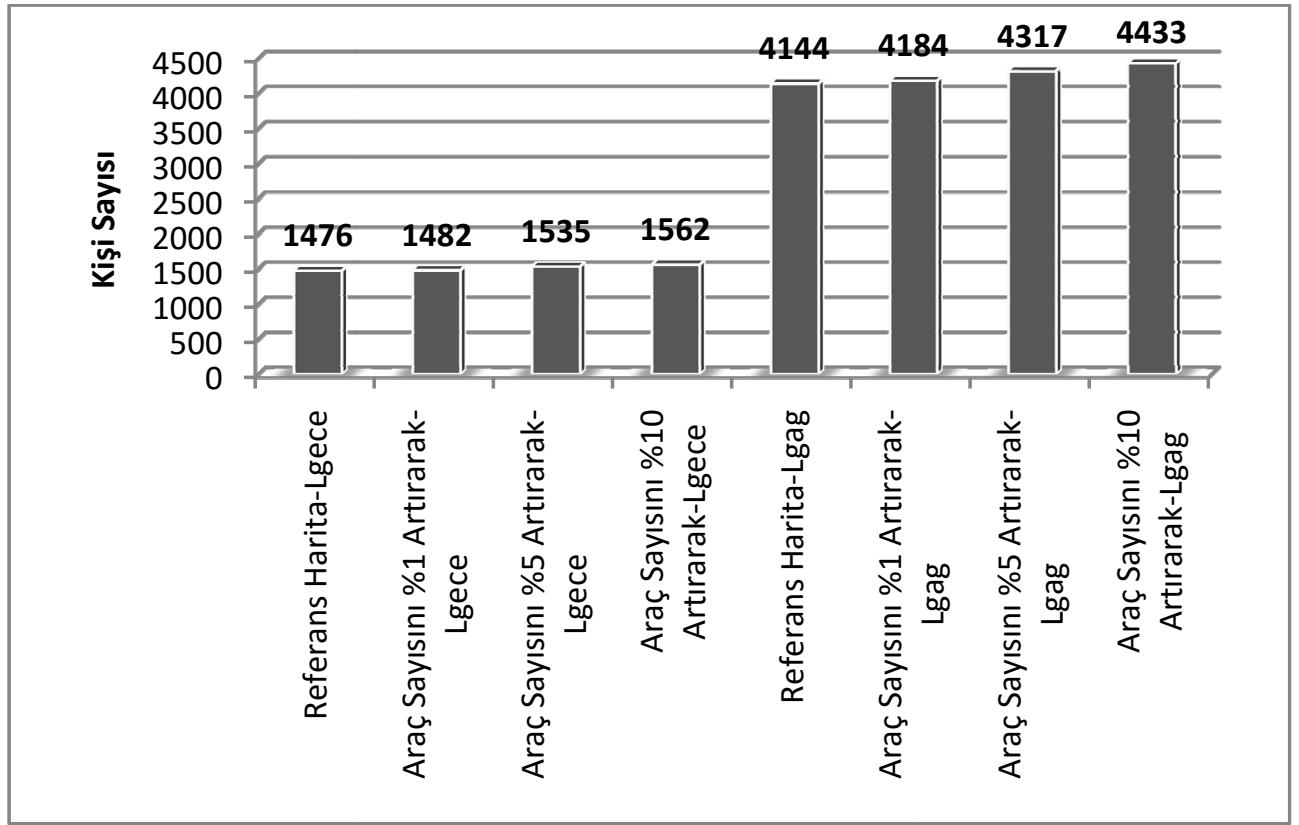

Şekil 10. Araç sayılarını değiştirerek çıkarılan haritalarda 55 dB(A)'nın üstünde etkilenen kişi sayısına göre karşılaştırma 
Şekil 11'de metrobüsler trafikten çıkarıldığg durumda yani ağır taşıt sayısının yaklaşık olarak yüzde 65 oranında azalması ile gürültüye maruz kalan kişi sayısının referans duruma göre nasıl değişeceği gösterilmiştir. Grafiğe göre metrobüsün trafikten kaldırılması ya da ağır trafik oranının yüzde 65 azaltılması rahatsızlık, uyku düzensizliği ve kardiyovasküler hastalık riskini yaklaşık olarak yüzde 6 oranında azaltmaktadır.

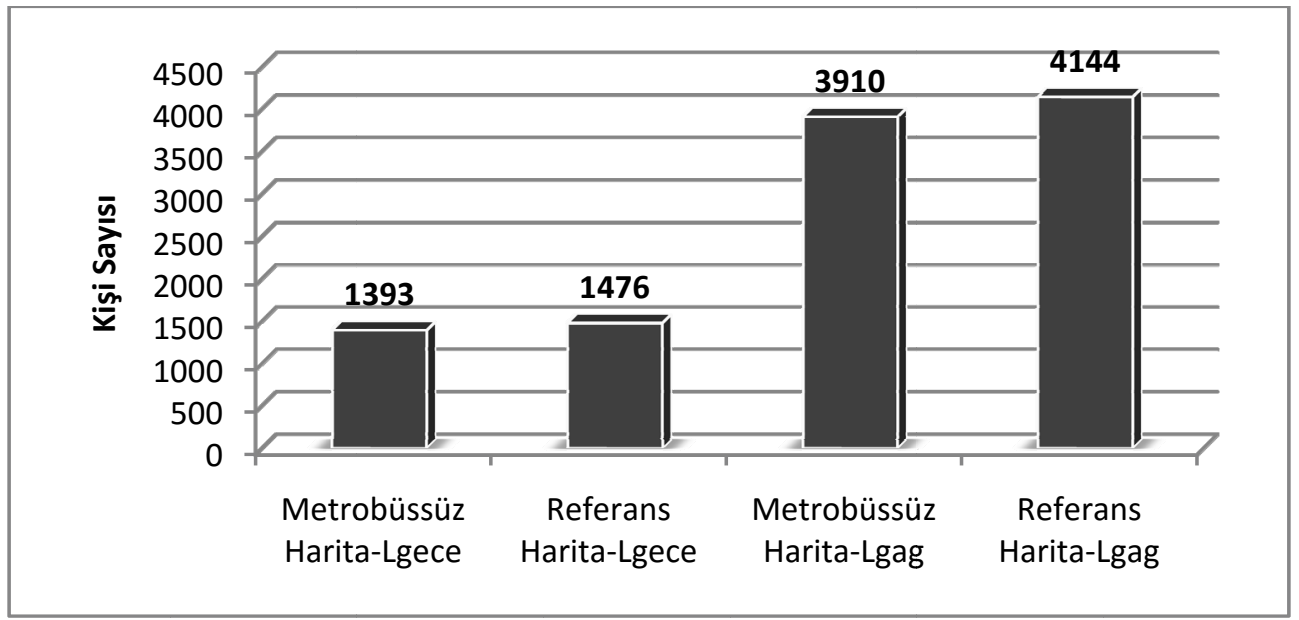

Şekil 11. Referans harita ile metrobüssüz haritanın 55 dB(A)'nın üstünde etkilenen kişi sayısına göre karşılaştırılması

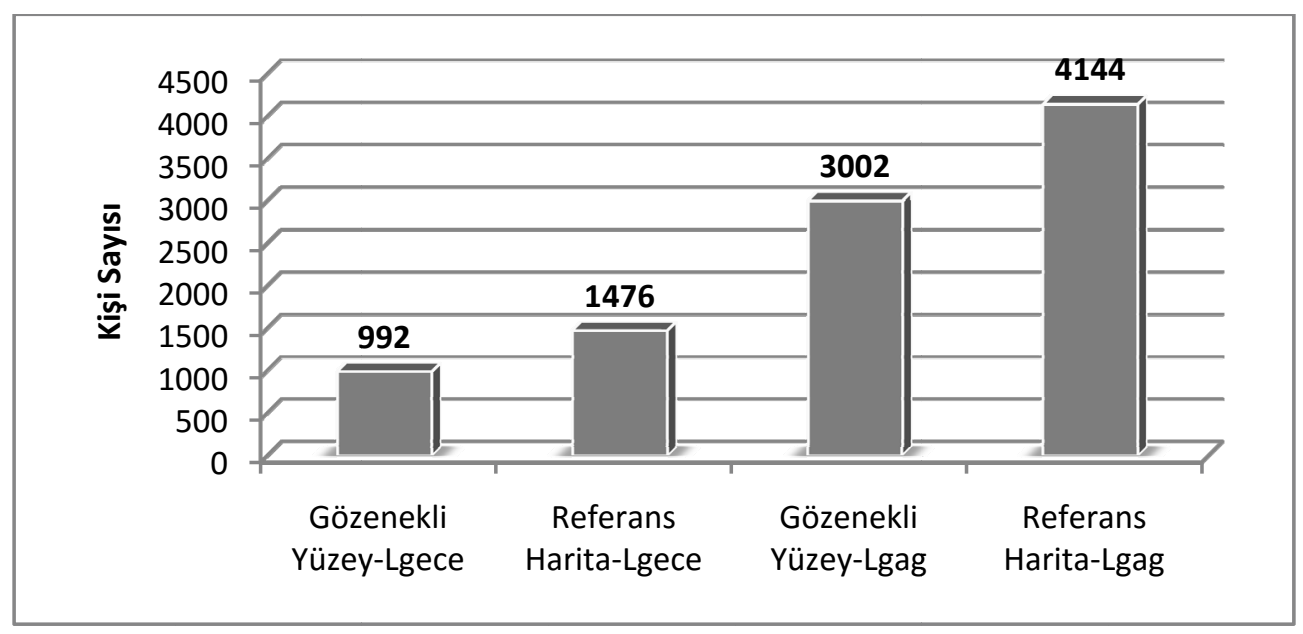

Şekil 12. Referans harita ile gözenekli yüzey yol tipinin seçildiği haritanın $55 \mathrm{~dB}(\mathrm{~A})$ 'nın üstünde etkilenen kişi sayısına göre karşılaştırılması 
Şekil 12'de yol kaplamasının yoğun gradasyonlu asfalt yerine hava boşluk oranı daha fazla olan ve bu nedenle de gürültüyü sönümleme özelliğine sahip gözenekli asfalt ile kaplandığında gürültüden etkilenimin referans değerlere göre değişimi gösterilmiş̧tir. $\mathrm{Bu}$ bağlamda, gözenekli asfalt kullanımıyla $55 \mathrm{~dB}(\mathrm{~A})$ ve üzeri $\mathrm{L}_{\text {gag gürültü seviyelerine maruz }}$ kalan kişi oranı yüzde 28 azalırken, $55 \mathrm{~dB}(\mathrm{~A})$ ve üzeri $\mathrm{L}_{\text {gece }}$ gürültü seviyelerine maruz kalan kişi oranının yüzde 33 azaldığı görülmektedir. Bu da ses seviyelerinin azaltılmasında gözenekli asfalt kullanımının, trafik hacmi, hızı ve kompozisyonu gibi trafik değişkenlerinden daha etkili olduğunu göstermektedir.

\section{SONUÇ VE ÖNERILER}

Karayolu gürültü haritalarının çıkarılmasındaki amaç çevrede yaşayanların gürültüden ne ölçüde etkilendiğini ortaya koyarak gürültü seviyelerini azaltmak için ne gibi önlemlerin alınabileceğini belirlemek ve yeni yerleşim bölgeleri için oluşacak gürülttüyü belirleyerek şehir planlarının gürülttï seviyelerini eşik değerler altında tutacak şekilde yapılmasını sağlamaktır. Ülkemizde, Avrupa Birliği uyum sürecinde Çevresel Gürültünün Değerlendirilmesi ve Yönetimi Yönetmeliği revize edilerek Avrupa Birliği Direktiflerine uyumlu bir hale getirilmiştir. SoundPlan 6.5 programı Avrupa Birliği Direktiflerine ve Çevresel Gürültünün Değerlendirilmesi ve Yönetimi Yönetmeliğine uyumlu olduğundan ve ülkemizde haritaların büyük kısmı bu program kullanılarak çıkarıldığından bu çalışmada da SoundPlan 6.5 programı kullanılmıştır. Öncelikle D-100 Karayolu Okmeydanı mevkisi için mevcut trafik ve yol üstyapı bilgileri kullanılarak referans gürültü haritaları oluşturulmuş, sonuçlar yol kenarında yapılan ölçümlerle karşılaştırılmıştır. Yol kenarı gürültü ölçümlerinden elde edilen D-100 karayolu gürültüsünün, referans gürültü haritasındaki karayolu gürültüsünden istatiksel olarak anlamlı olarak farklı olmadığı gösterilmiştir. Fakat yol kenarı gürültü ölçümleri kullanılarak hazırlanan gürültü haritası etki analiz sonuçları, referans harita etki analiz sonuçlarından oldukça farklıdır. $\mathrm{Bu}$ da gürültü haritalamasında gürültü ölçümlerinin dikkate alınması gerektiğini, özellikle gürültü eylem planlarında gürültü azaltımı gereksinimi saptanmış bölgelerin uzun dönemli gürültü ölçümleriyle doğrulanmasının gerekliliğini göstermektedir.

Referans haritaya göre rahatsızlık, uyku bozukluğu ve kardiyovasküler hastalık riski taşıyan kişi sayısı belirlenmiştir. Nüfusun $\mathrm{L}_{\mathrm{gag}}$ değerlerine göre yaklaşık yüzde 11'i, $\mathrm{L}_{\text {gece }}$ değerlerine göre ise yaklaşı yüzde 4'ü $55 \mathrm{~dB}(\mathrm{~A})$ ve üzeri gürültü seviyelerine maruz kalmaktadır. Bu bağlamda, D-100 Karayolu Okmeydanı mevkisinde rahatsızlık ve kardiyovasküler hastalık riski taşıyan kesim toplam nüfusun yaklaşık yüzde 11'ini, uyku bozukluğu riski taşıyan kesim toplam nüfusun yaklaşık yüzde 4'ünü oluşturmaktadır. $\mathrm{Bu}$ eşik değerin üzerinde kalan nüfus oranın D-100 karayolu gibi trafiğin yoğun ve konutların yola çok yakın olduğu bir bölgede bu şekilde düşük seviyede olmasının sebebi çalışma yaptı̆̆ımız alanda nüfusun yaklaşık yüzde 93'lük gibi büyük bölümünü kapsayan Talatpaşa Mahallesi'nin büyük kısmının yol kotundan düşük seviyede kalmasıdır.

Daha sonra aynı bölge için araç hızları, araç sayıları ve yol üst yapı malzemesi gibi veriler değiş̧irilerek gürültü haritaları çıkarılmış ve hastalık riski taşıyan kişi sayısındaki değişimler incelenmiştir. D-100 Karayolu Okmeydanı mevkisi için oluşturulan gürültü haritaları incelendiğinde gürültü seviyelerinin artan hız ve araç sayısı ile arttı̆̆g; yol üstyapısı olarak gözenekli asfalt kullanımıyla da azaldığı görülmüştür. Trafik hızının 5 
km/saatlik değişimiyle hastalık riskinde yaklaşı yüzde 8-9'luk bir değişim olduğu, trafik hacminin yüzde 5 artışıla hastalık riskinde yaklaşık yüzde 4 , yüzde 10 artışılla ise hastalık riskinde yaklaşık yüzde 6-7 civarında artış olduğu bulunmuştur. Metrobüs trafikten kaldırıldığında ya da ağır araç sayısının yüzde 65 civarında azaltılmasıyla ise hastalık risklerinde yaklaşık yüzde 6'llk bir düşüş olmuştur. Metrobüsün trafikten çekilmesinin yani ağır araç sayısının yüzde 65 azaltılmasının etkisinin bu kadar düşük olmasının nedenleri ağır araçların trafiğin sadece yüzde 3-4 civarında küçük bir kısmını oluşturması ve metrobüs hızının trafik akış hızına göre çok daha yavaş (20-40 km/saat) olduğundan ortaya çıkardığı gürülttü seviyelerinin da oldukça düşük olması şeklinde düşünülebilir. Yol üstyapı malzemesi olarak gözenekli asfalt kullanıldığında ise mevcut duruma göre hastalık riski yüzde 28-33 civarında azalmaktadır. Bu bağlamda, gürültü azaltma etkinliğinde en iyi alternatifin gözenekli asfalt kullanımı olduğu görülmüştür. Bunun olası nedeni de gözenekli asfaltın gürültüyü absorbe ederek kaynağında azaltmasıdır. Gürültü azaltma yöntemlerinin sağlık etkilerini inceleyen teorik bir çalışmada da gözenekli asfaltın hız sınırı uygulamasına göre daha etkin bir yöntem olduğu gösterilmiştir [20]. Bu bağlamda, sonuçlar belirtilen önceki çalışmayı da destekleyici niteliktedir.

Sonuç olarak, gürültü günümüzde insan sağlı̆̆ını ve performansını olumsuz olarak etkilemektedir. Karayolu gürültüsü de şehirleşmenin gittikçe arttığı ülkemizde sağlık üzerine büyük tehditler oluşturmaktadır. Çalışmamız göz önüne alınarak araç hız limitlerinin azaltılması, toplu taşımaya yönelimin arttırılması, ağır araçlara sınırlandırmalar getirilmesi ve yol üstyapı malzemesi olarak yoğun gradasyonlu asfalt yerine gözenekli yüzeye sahip asfaltın kullanılması karayolu kenarlarında yaşayan insanların trafik gürültüsünden rahatsızlıklarını tamamen yok etmese de büyük ölçüde azaltacağı saptanmıştır. Eylem planı gerektiren, gürültü seviyelerinin eşik değerlerin üzerinde kaldığı bölgelerde yukarıda açıklanan yöntemlerden bir veya birkaçı beraber uygulanarak gürültünün azaltılması sağlanabilir.

\section{Kaynaklar}

[1] Guidelines for community noise, adverse health effects of noise, World Health Organization (WHO), 2012.

http://www.who.int/docstore/peh/noise/Comnoise3.htm(05/10/13)

[2] Evans, G.W., Hygge, S., Bullinger, M., Chronic noise and psychological stress, Psychological Science, 6 (6), 333-338, 1995.

[3] Position paper on dose response relationships between transportation noise and annoyance, Office for Official Publications of the European Communities, Luxembourg, 2002

http://ec.europa.eu/environment/noise/pdf/noise_expert_network.pdf.

[4] Colten, H. R., Altevogt, B. M., Sleep Disorders and Sleep Deprivation, National Academies Press (US), Washington, DC, 2006.

[5] Miedema, H.M.E., Passchier-Vermeer, W., Vos, H., Elements for a position paper on night-time transportation noise and sleep disturbance, Netherlands Organization for Applied Scientific Research, 2003. 
Trafik Gürültüsünü Etkileyen Faktörlerin SoundPlan 6.5 Programı ile İncelenmesi

[6] Berglund, B,.Lindvall, T., Community noise, Archives of the Center for Sensory Research, 2(1), 1-195, 1995.

[7] NoiseObservationand Information Service for Europe - Noise, European Environment Agency and European Topic Centre on Spatial Information and Analysis, 2012. http://noise.eionet.europa.eu/index.html(02/09/13)

[8] Çevresel gürültünün değerlendirilmesi ve yönetimi yönetmeliği, Ankara, 2010.

[9] Sandberg U.,Ejsmont, J.A., Tyre/Road Noise Reference Book, Informex, Kisa, Sweden, 2002.

[10] Sandberg. U.,Tyre/Road NoiseMythsandRealities, Proceedings of Inter-Noise, TheHague, The Netherlands, 2001.

[11] Mogrovejo, D.,Flintsch, G., Izeppi, E.D.L., McGhee, K., Effect of air temperature and vehicle speed on tire/pavement noise measured with on-board sound intensity methodology, Blacksburg, Virginia, 2012.

[12] Mitchell, P.,Speedandroadtrafficnoise: the role thatlowerspeedscouldplay in cuttingnoisefromtraffic, UK NoiseAssociation, UK, 2009

[13] Ongel, A.,Kohler, E., Harvey, J., Principal Components Regression of Onboard Sound IntensityLevels, Journal Of Transportation Engineering-Asce,134,11,459-466, 2008.

[14] Position Paper on Dose Response Relationships between Transportation Noise and Annoyance, Office for Official Publications of the European Communities, Luxembourg, 2002.

[15] Miedema, H. M. E.,Passchier-Vermeer, W., Vos, H., Elements for a Position Paper on Night-time Transportation Noise and Sleep Disturbance, Organization for Applied Scientific Research, Netherlands, 2003.

[16] Babisch, W., Road Traffic Noise and Cardiovascular Risk. Noise\&Health, 10 (38), 27-33, 2008.

[17] Manvell, D. The Use of Measurements \& GPS for Noise Mapping Joint BalticNordic Acoustics Meeting 2004, Mariehamn, Aland, Finlandiya, 8-10 Haziran, 2004.

[18] Burden of disease from environmental noise, quantification of healthy life years lost in Europe. WHO Regional Office for Europe: Copenhagen, 2011. http://www.euro.who.int/_data/assets/pdf_file/0008/136466/e94888.pdf $(09 / 06 / 2012)$

[19] D'Hondt E, Stevens M. Participatory Noise Mapping. Pervasive 2011, San Francisco, CA, USA, 12-15 Haziran, 2011.

[20] Ongel, A., F. Sezgin. Assessing the Effects of Noise Abatement Measures on Health Risks: A Case Study in Istanbul. Environmental Impact Assessment Review 56, 280287, 2016. 